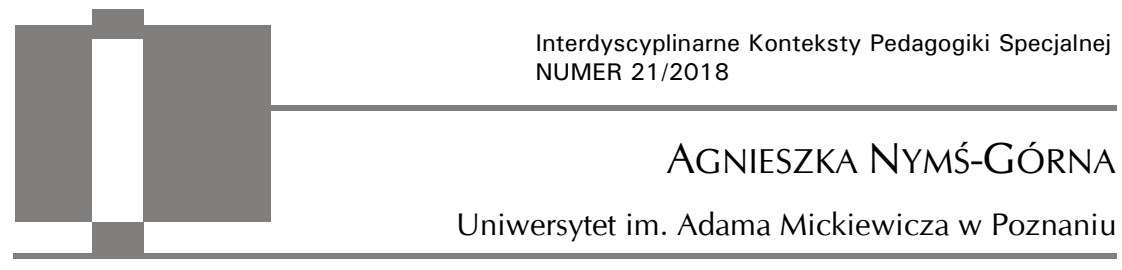

\title{
Sprawozdanie z Ogólnopolskiej Konferencji Wytwarzanie intymności. O codziennych wyzwaniach (Wrocław, 4 grudnia 2017)
}

Dnia 4 grudnia 2017 r. we Wrocławiu odbyła się Ogólnopolska Konferencja Naukowa Wytwarzanie intymności. O codziennych wyzwaniach. Organizatorami wydarzenia był Instytut Socjologii Uniwersytetu Wrocławskiego Zakład Socjologii Płci i Rodziny oraz Polskie Towarzystwo Socjologiczne o. Wrocław. Była to już czwarta edycja tego typu konferencji.

Na początku głos zabrał dr Paweł Czajkowski. Przedstawił wystąpienie za prof. dr. hab. Rafała Drozdowskiego, który niestety nie mógł dotrzeć na wydarzenie ze względów zdrowotnych. Prelegent mówił o udziale nowych technologii oraz tendencjach rynkowych w pojmowaniu współczesnej intymności. Następnie głos zabrała dr hab. prof. UWr Dorota Majka-Rostek. Profesor zastanawiała się na ile intymność jest aktualnie prywatna, a na ile już publiczna. Przytoczyła także koncepcje takich klasyków, jak: Anthonego Giddensa, Zygmunta Baumana czy Ulricha Becka. Jako ostatnia wystąpiła dr Ewa Banaszak, która z kolei przytoczyła założenia oraz wybrane wyniki swoich badań. Mówiła o tym, że cielesność i intymność nie są łatwymi tematami badawczymi. Wspomniała również o tym, że w rodzinie cielesna współobecność wpływa na jakość więzi. Tymi wystąpienia konferencja została otwarta.

Część pierwszą moderował dr Paweł Czajkowski. Swoją wypowiedź przedstawił dr Robert Florkowski, który mówił o intymności w BDSM. Wspominał o tym, że osoby będące zwolennikami tej praktyki zwracają 
większą uwagę na potrzeby partnera oraz są bardziej empatyczne. Mówił też o roli haseł bezpieczeństwa $\mathrm{w}$ takiej relacji. Podzielił się również ze słuchaczami doświadczeniami z własnej praktyki psychoterapeutycznej. Kolejna wystąpiła mgr Paulina Stępnień, której wystąpienie wzbudziło wiele kontrowersji ze względu na poruszaną tematykę. Przedstawiła ona kwestię intymnej relacji z plastikową lalką imitującą realną kobietę, co jest niezwykle powszechne w Japonii oraz Stanach Zjednoczonych. Podkreśliła, że nie dotyczy to tylko osób samotnych. Przedstawiła także w odniesieniu do tej problematyki koncepcję relacji intymnych w ujęciu Lynn Jamieson. Następnie głos zabrał mgr Grzegorz Wiktorowski, który wyczerpująco omówił przemiany intymności $\mathrm{w}$ amerykańskim protestantyzmie fundamentalistycznym i ewangelikalnym. Na zakończenie tej sesji przemówiła mgr Agnieszka Sobik, która zapoznała wszystkich uczestników konferencji z wynikami badań własnych na ważny temat dotyczący traktowania intymności osób homoseksualnych.

Po przerwie kawowej część drugą moderował dr Robert Florkowski. W tej części zaprezentowali: się mgr Monika Mucha, mgr Sebastian Surendra oraz mgr Joanna Jankowska. Mówili na temat postrzegania intymności oraz dzielenia się nią $\mathrm{w}$ cyberprzestrzeni, a konkretniej na rozmaitych portalach społecznościowych (przede wszystkim Facebook, Instagram i Twitter) oraz programach typu reality show (na przykład Big Brother, Warsaw Shore, Naga randka, Czar nagości, Randka w łóżku). Z kolei dr Julita Czernecka przytoczyła wyniki badań, które zostały zrealizowane wśród Internautów zarejestrowanych na portalu Sympatia.pl. Podkreśliła $\mathrm{w}$ swoim wystąpieniu, że $\mathrm{w}$ wirtualnej rzeczywistości mogą rodzić się realne uczucia.

Dr hab. prof. UWr Dorota Majka-Rostek moderowała trzecią część konferencji, która dotyczyła intymności w rodzinie. Mgr Agnieszka Nymś-Górna wprowadziła słuchaczy w inne pojmowanie intymności odwołując się do rodziny. Tę myśl kontynuowała prof. dr hab. Ewa Malinowska, która intymną relację rozpatrywała w stosunkach babci z wnuczką. Społeczny kontekst współczesnego zjawiska dobrowolnej bezdzietności przedstawiła dr Emilia Garncarek. Z kolei dr Andrzej Perzanowski mówił o bliskości i intymności w opiece rodzinnej w psychiatrii. Posługiwał się przykładami ze Szpitala Psychiatrycznego w Choroszczy (niedaleko Białegostoku). Na zakończenie tej sesji głos zabrała dr Krystyna Dzwonkowska-Godula, która zaprezentowała tematykę intymności rodzących kobiet. Wspomniała także o roli Fundacji Rodzić po Ludzku. 
W czwartej sesji moderowanej przez dr Ewę Banaszak zaplanowano kolejne referaty. Dr hab. Marioli Bieńko z tematyką intymności o związkach młodych dorosłych, mgr Aleksandry Drabiny-Różewicz i dr Agaty Krasowskiej dotyczący intymności młodych pracowników prekaryjnych, mgr Agaty Rejowskiej-Pasek o humanistycznych przysięgach ślubnych, dr Jolanty Klimczak wokół intymności wytwarzanej w przestrzeni każdego mieszkania oraz mgr Klaudii Renusch wykorzystującej do swych analiz dzienniki Sławomira Mrożka.

Cała konferencja przebiegała w bardzo przyjemnej atmosferze. Stała się przestrzenią wymiany myśli oraz rozwoju. Warto podkreślić, że dzięki wystąpieniom ujmującym tę tematykę $\mathrm{z}$ tak wielu perspektyw możliwe stało się rozpoznanie aktualnego stanu badań i teorii w tym zakresie, a także poszukiwanie inspiracji do dalszych dociekań naukowych.

DOI: https://doi.org/10.14746/ikps.2018.21.18 